\title{
Coordination Analysis of Over Current Protection Using ETAP Software: A Case Study in PT Indocement Tunggal Prakarsa Tarjun, Kotabaru, South Kalimantan
}

\author{
Aditiya Setiawan ${ }^{* 1}$, Ramadoni Syahputra ${ }^{1}$, Anna Nur Nazilah Chamim ${ }^{1}$, and Jeckson ${ }^{2}$ \\ ${ }^{1}$ Department of Electrical Engineering, Universitas Muhammadiyah Yogyakarta \\ Jl. Lingkar Selatan, Tamantirto, Kasihan, Yogyakarta, Indonesia \\ ${ }^{2}$ Department of Electrical Engineering, Universitas Muhammadiyah Lampung \\ Jl. Zainal Abidin Pagar Alam 14. Lahuban Ratu, Bandar Lampung, Indonesia \\ *Corresponding author, e-mail: eka.eza4@gmail.com
}

\begin{abstract}
PT Indocement Tunggal Prakarsa Tarjun, Tbk Plant 12, is the largest cement company in Kalimantan. The growing industrial world in the field of cement that is very rapidly will significantly affect the speed of the economy. Thus the increase in the field of electricity will be more felt. PT Indocement Tunggal Prakarsa Plant 12, located in South Kalimantan, requires a reliable electrical system, both in terms of its power supply, in terms of backup of installed electrical systems, as well as safeguards that meet the electricity standards. In the short-circuit settlement is not desired, then the protection of the current relays more with proper coordination protection and reliable required. The coordination of the protection of the current relay is more necessary than the others in order to occur short circuit occurs in the field. No widespread damage occurred in its electricity and existing industrial equipment. To maintain the condition of the electric power system in optimum absence, a re-study of the coordination of current relational protection in PT Indocement Tunggal Prakarsa, Tbk Plant 12. This final project will discuss coordination analysis of overcurrent relay protection at PT. Indocement Tunggal Prakarsa, Tbk. In analyzing the coordination of overcurrent protection, then using several methods in a more coordinated way with coordination protection resetting using ETAP software. They are also resetting coordination protection overcurrent relays using manual calculations. After making the comparison, it can be seen as more current relay protection installed in the field. Some do not work well. It is pronounced in the work of existence, which does not match the standard ie, 0.2 - 0.35 seconds from the IEEE.
\end{abstract}

Keywords: Industry, Coordination of Protection, Quick Response, Over-Current Relay

\section{Introduction}

The need for electricity from year to year is increasing and where electricity is the primary need of various kinds of human activities where the quality and continuity of electricity supply services is essential [1]. This is very demanding for the supply of electrical energy to increase its reliability in the distribution of electrical energy to the installed load. In today's human life, which is increasingly modern, the use of electrical energy has an important role both in the household sector, lighting, communication, industry, and so on [2].

PT Indocement Tunggal Prakarsa Tarjun, Tbk Plant 12, is the largest cement company in Kalimantan. The growing industrial world in the field of cement that is very rapidly will significantly affect the speed of the economy. Thus the increase in the field of electricity will be more felt. PT 
Indocement Tunggal Prakarsa Plant 12, located in South Kalimantan, requires a reliable electrical system, both in terms of its power supply, in terms of backup of installed electrical systems, as well as safeguards that meet the electricity standards. PT Indocement Tunggal Pakarsa Tbk P-12 must have good protective coordination in overcoming and preventing short-circuiting that occurs. To increase the reliability of the electrical system and also to minimize interference, better overcurrent protection coordination is needed. The overcurrent protection relay coordination aims to finalize the impact caused by a short circuit with a better protection coordination which will make the protection system more selective and discriminatory if frequent disturbances occur that can result in damage to the system and electrical equipment, and with the coordination of protection can allocate protection disturbance and maintain the system to remain good, and avoid damage to equipment so that the quality and quantity of the resulting product is maintained.

\section{Literature Study}

\section{II.1 Electrical Power Distribution System}

The electricity distribution system is a process of channeling electrical energy from the transmission network to customers who need electricity [3]. The power distribution system is divided into two parts, namely the Primary Distribution System and the Secondary Distribution System [4].

In general, the main components of the power distribution system consist of a primary distribution system and a secondary distribution system. One important component in a distribution system is the protection system. This protection system plays an important role in ensuring the continuity of the system [5].

The primary distribution system is a medium voltage distribution network that originates from a transmission network that is reduced from the substation to a voltage of $20 \mathrm{kV}$ or an intermediate network and then distributed to all locations of electric subscribers [6]. The secondary distribution system is a distribution network that is distributed to customers after the voltage is lowered to a low voltage that is $220 \mathrm{~V}$ or $380 \mathrm{~V}$. The secondary distribution system will include a transformer in which the transformer functions as a voltage reducer to be distributed to the electric customer. The main components in an electrical power distribution system was shown in Figure 1.

\section{2 Protection in Distribution System}

The electricity protection system is a protection system that is installed on all-electric power equipment, such as generators, transformers, distribution and transmission networks, insulation, and others on electric power system equipment [7]. Distribution system protection equipment was shown in Figure 2. So that all protection systems are in an abnormal condition, what is meant by abnormal in electric power protection systems are short circuit, over, and less voltage, overload, the system frequency goes up and down, and so on.

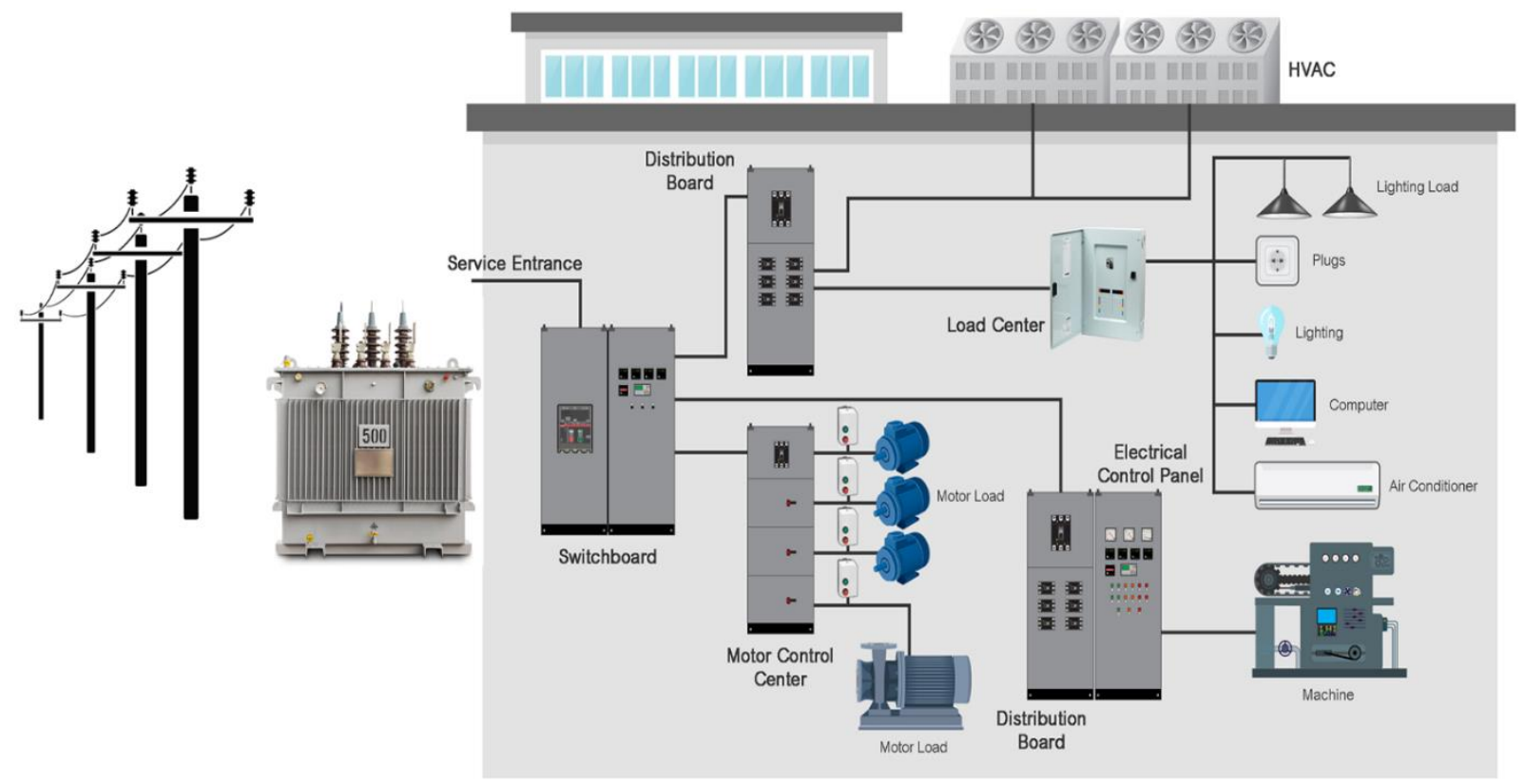

Fig. 1. The main components in an electrical power distribution system 


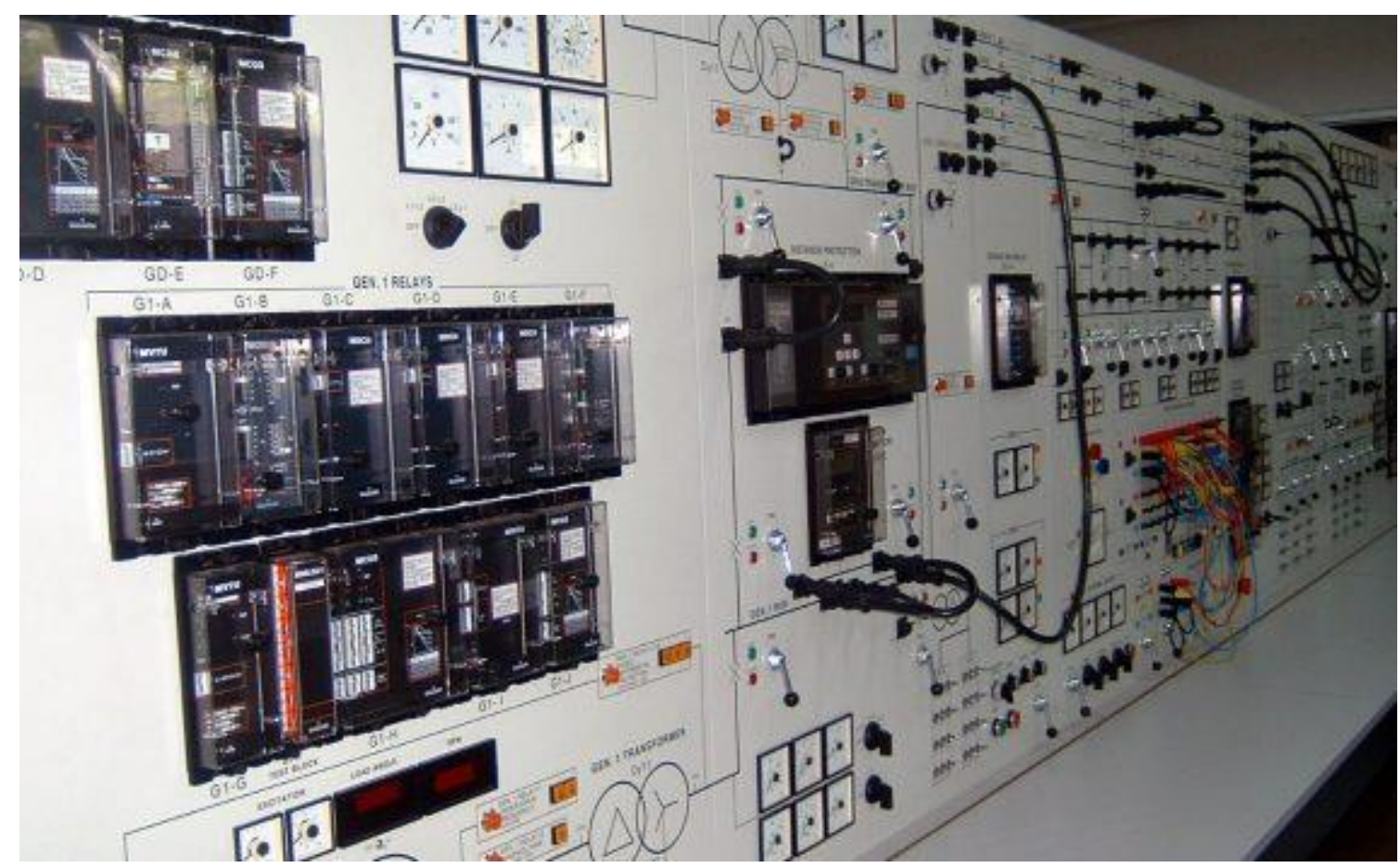

Fig. 2. Distribution system protection equipment

The objectives of the Electric Power Protection System are:

a. To maintain and reduce electrical equipment damage caused by disruptions.

b. To isolate the disturbances that occur so as not to become more extensive.

c. Providing electric service systems with high reliability and reliability to be distributed consumers.

d. Securing from the danger posed by electricity to humans.

Short-circuit current depends on the amount of source that generates the system, the value of equipment resistance, and the overall system reactance value to the point of disturbance. Shortcircuit current sources can come from generating systems, generators, synchronous motors, and induction motors.

The generator is an electrical energy generating device that works to convert mechanical energy into electrical energy. In addition to getting power supply from the PLN power plant as the primary power generation system, several large industries also have their power supply from generators that can function as follows:

a. As a backup unit (emergency), which is run during emergencies or when there are outages to the central generating system. b. As an aid generating unit that can help supply electricity from the PLN power station during peak load.

In the event of a short-circuit fault, the generator contributes to the large short-circuit current that occurs. Prime movers drive the generator. When a short circuit occurs, the generator will continue to be controlled by the prime mover and continue to produce a voltage as long as the excitation field is maintained and during the generator's rotation at an average speed. This generated voltage produces a large current flowing to the point of interference. Current flowing is only limited by the generator impedance and the circuit impedance from the generator to the point of interference.

The generator reactance changes overtime transiently after the onset of the fault. The types of reactance values are as follows:

a. $X " d=$ Sub transient reactance / Sub transient reactance.

$\mathrm{X}$ "d is the reactance value that determines the magnitude of the short circuit current shortly after an interruption.

b. $X^{\prime} d=$ Transient Reactance

$X^{\prime} d$ last about 2 seconds and increases until it reaches the final reactance value.

c. $X d=$ Synchronous Reactance

$\mathrm{Xd}$ is the reactance value that determines the amount of current flowing after the steady-state condition is reached. This is achieved after a few 
seconds after the short circuit occurs.

\section{Methodology}

To get the formulation of analysis and problem solving, complete, relevant, and objective data and facts, collection and truth can be trusted. Therefore, writing to collect data, analyze case studies, and compile this final project research report using several methods, namely:

a. Study of literature

The authors carry out activities by looking directly for literature related to protection equipment on the distribution network.

b. Literature review

The author collects data obtained based on internet book references and reports available at plant 12 PT Indocement Tunggal Prakarsa Tbk, which deals with the problem to be discussed. Figure 3 shows the location of PT Indocement Tunggal Prakarsa Tbk in South Kalimantan province.

c. Survey

The author conducts a question and answers activities for PT. Indocement Tunggal Prakarsa Tbk, regarding the issues to be discussed.

Figure 4 explains the steps of the research carried out. To give a precise Figure, the picture is given a more comprehensive explanation.

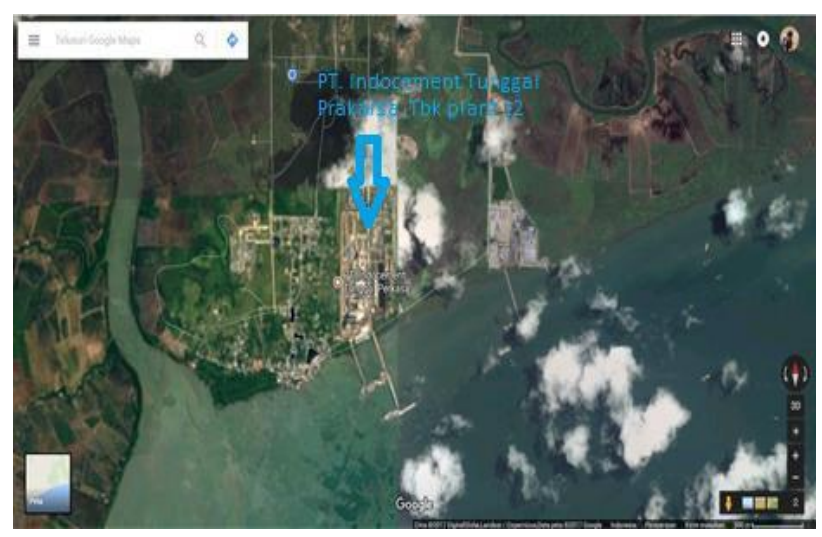

Fig. 3. Location of PT Indocement Tunggal Prakarsa Tbk

The preliminary study is the initial stage in the writing methodology. In this stage, a field study is carried out by observing the situation in the cement industry in South Kalimantan directly. Where in conducting this final project research, the researcher made observations made directly to know the initial information about the environment and the situation of the cement industry. The location of the research planning was carried out at PT Indocement Tunggal Prakarsa Tbk, Tarjun, Kotabaru district, South
Kalimantan province.

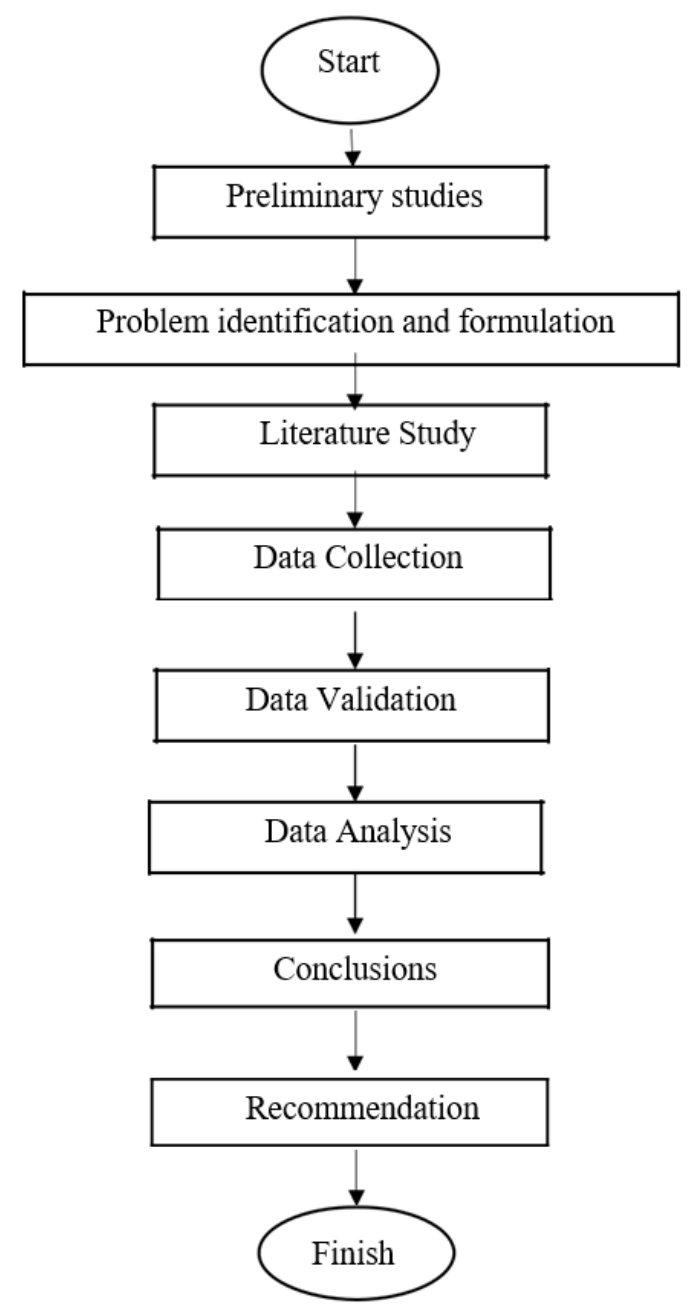

Fig. 4. The research steps of this study

After conducting a preliminary study, problems in the industrial area can be identified. Then we explore the causes of problems that occur by making observations in the field by asking directly to the field supervisor in the company and those who are experts in their fields.

The issue raised as a topic is the relay coordination system installed in Plant 12. Therefore, in this final project will make a simulation model of overcurrent relay protection coordination by using ETAP 12.6 Software.

A literature study is conducted in order to get information about important things, both theories, methods, and also the same concepts with the issues raised by searching for information in the form of textbooks, the internet, and other reliable sources.

This data collection is done by direct observation in the industrial area, interviews with supervisors and supervisors of related electrical and mechanical industry companies, and collecting the required data sheets such as the single line diagram of Plant 8 
network, the relay coordination data that has been installed, and the load data used factory.

After the data is collected, the next step is data processing. Existing data are selected according to needs in the field. In data processing, a grouping of relay protection settings, delivery dates, and other data is carried out. Data processing is done with ETAP 12.6 software, and after that, testing is done with ETAP 12.6 software.

The simulation will get a result that will be analyzed. The data to be analyzed is about the coordination of the protection system used by giving problems to the network and observing the protection system. If there is an error setting and result in wrong coordination, the relay will be reset to get a more selective coordination performance. After the relay settings are made, and it is known that the system is coordinating well, it is hoped that it can minimize damage to the equipment on the network.

\section{Results and Discussion}

Single line overcurrent protection diagram of the overcurrent relay generator at PT Indocement Tunggal Prakarsa, Tbk Plant 12, was created using ETAP 12.6 software based on field data and shown in Figure 5.
To do the calculation that is generated, we need a generator installed in the field, with a $50 \mathrm{MW}$ capacity generator, a voltage of $11 \mathrm{kV}$, and an $\mathrm{X}$ "d reactance of $19 \%$.

In calculating the short circuit current, then it uses two parameters, namely the maximum and minimum short circuit current. The maximum short circuit is a short circuit that works on 3 phases during $1 / 2$ cycle, and the minimum short circuit works on 2 phase 30 cycle. To simplify the calculation that is done later, then used Figure 5 and Figure 6, which is where this single line image using impedance calculations in the previous section.

In the first 3 phase short circuit current calculation, the impedance with a voltage level of $33 \mathrm{kV}$ is used, because of the short circuit interference that occurs at the $33 \mathrm{kV}$ voltage level, the calculation is as follows: Zeki $1=9.45$, Zeki $2=$ 313.02, Zeki $3=318.02$, Zeki $4=292.04$, Zeki $5=$ 306.1 , and Zeki $6=65.81$.

Based on the results of the short circuit analysis, three-phase short circuit current is obtained, 2725.02 ampere. Based on the results of the short circuit analysis, two-phase short circuit current is also obtained, 2725.02 ampere.

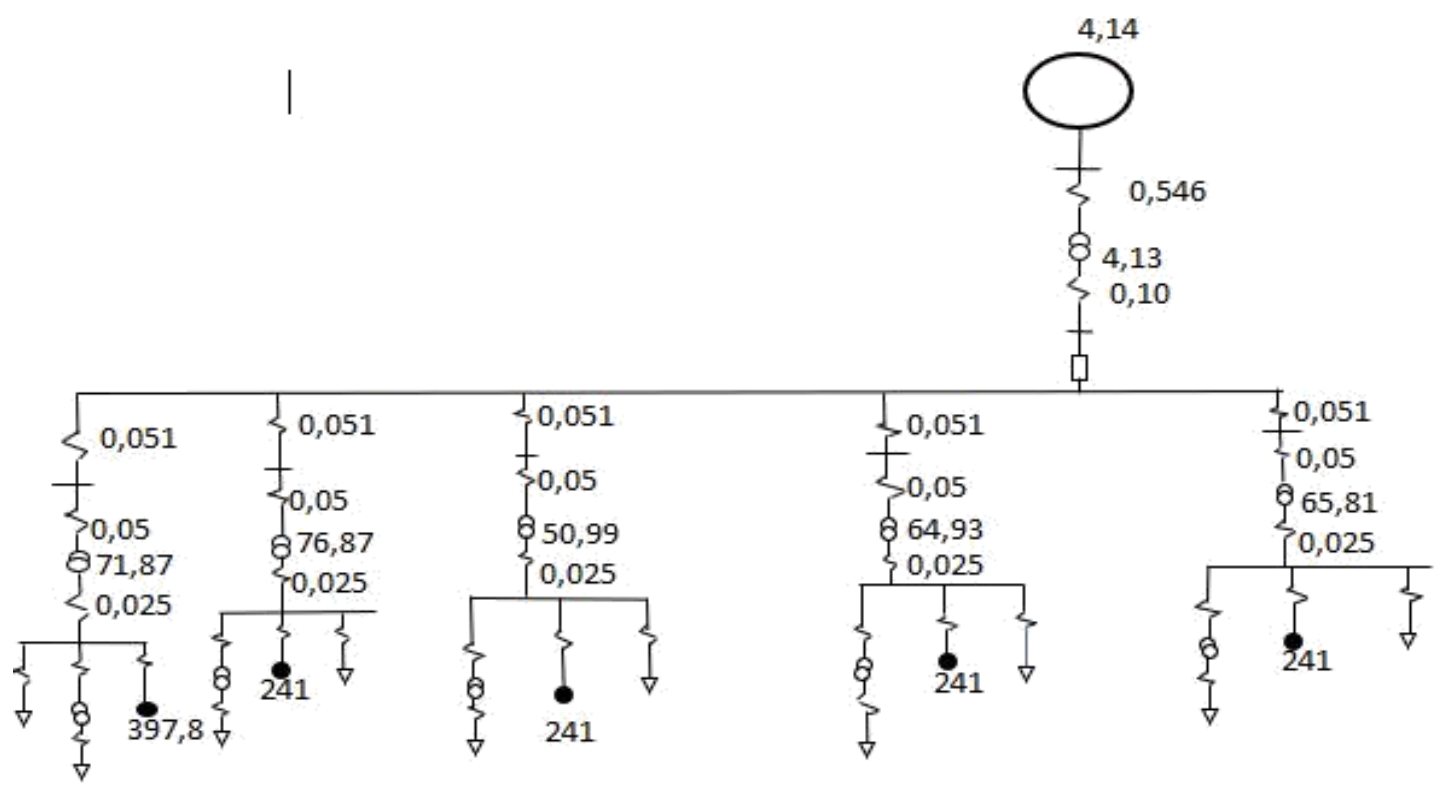

Fig. 5. The single line diagram of short circuit analysis at PT Indocement Tunggal Prakarsa Plant 12 


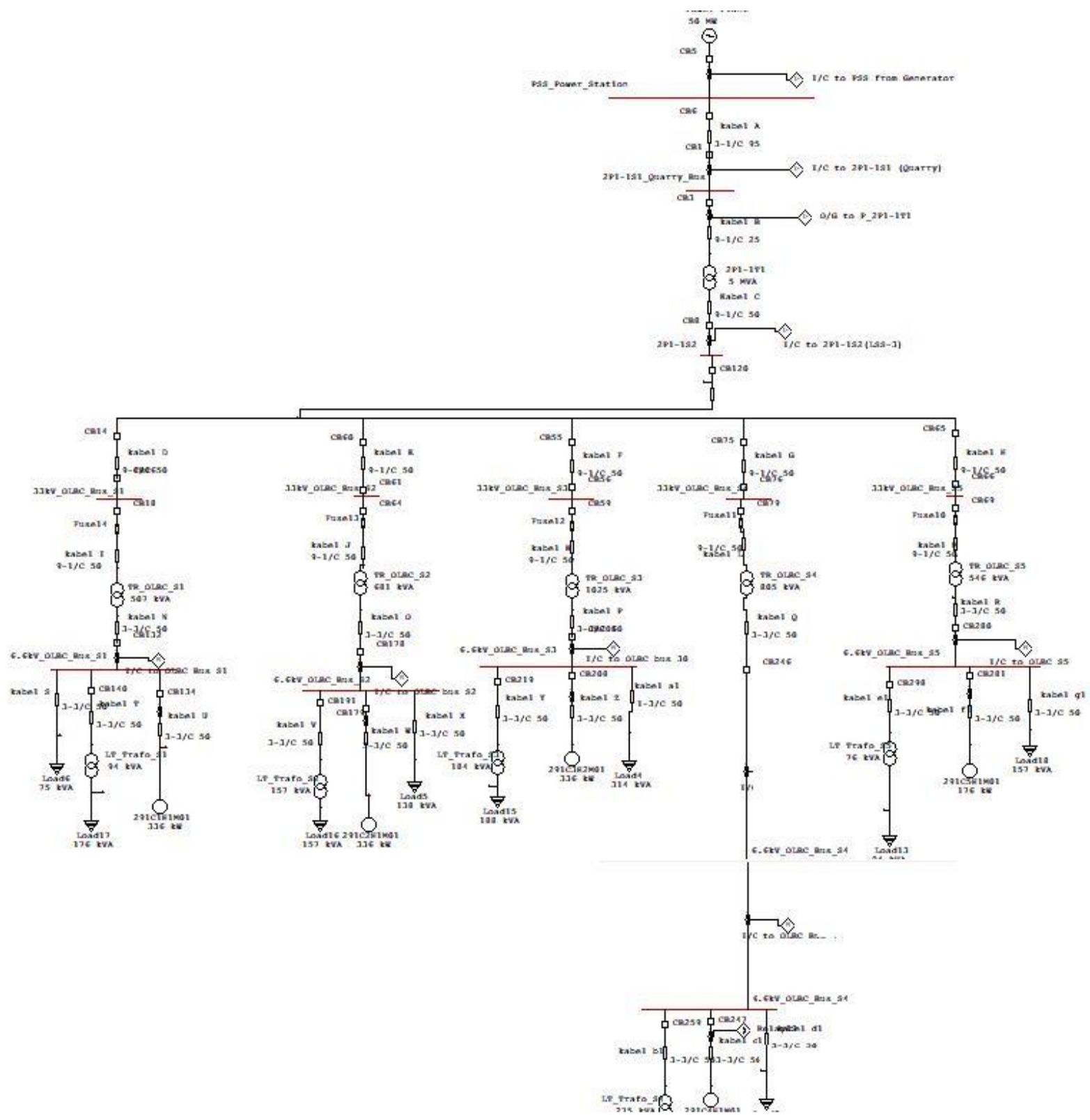

Fig. 6. The single line diagram of overcurrent protection at PT Indocement Tunggal Prakarsa Plant 12

TABLE I

RESUlts OF SHORT CIRCUIT ANALYSIS

\begin{tabular}{cccc}
\hline \hline No. & $\begin{array}{c}\text { Protection } \\
\text { Zone }\end{array}$ & $\begin{array}{c}\text { Short circiuit } \\
\text { of 3 Phase } 1 / 2 \\
\text { Cycle }(\mathrm{A})\end{array}$ & $\begin{array}{c}\text { Short circiuit } \\
\text { of 3 Phase 30 } \\
\text { Cycle (A) }\end{array}$ \\
\hline 1 & Zone 1 & 24.830 & 17.640 \\
2 & Zone 2 & 9.220 & 7.421 \\
3 & Zone 3 & 3.028 & 2.499 \\
4 & Zone 4 & 3.058 & 2.610 \\
5 & Zone 5 & 3.008 & 2.810 \\
6 & Zone 6 & 3.108 & 2.492 \\
7 & Zone 7 & 2.881 & 2.448 \\
\hline \hline
\end{tabular}

Resetting for overcurrent relay coordination using the ETAP software simulation will use data from short circuit current using the short circuit analysis facility in the ETAP software.

In order to facilitate an observation made, a short circuit current that has been simulated using the short circuit analysis facility will be summarized in the table below, namely Table 1, where the table is divided into various protection zones at the generator in Quarry.

Next is the Time Current Curve (TCC) chart analysis of the three installed heights and is simulated in the protection zone 1 . Where there is a coordination setting for overcurrent relay protection installed in the field. Coordination of overcurrent 
relay protection coordination using manual calculations, resetting for overcurrent protection using ETAP software will be indicated in the Figure 7, Figure 8, and Figure 9 below.

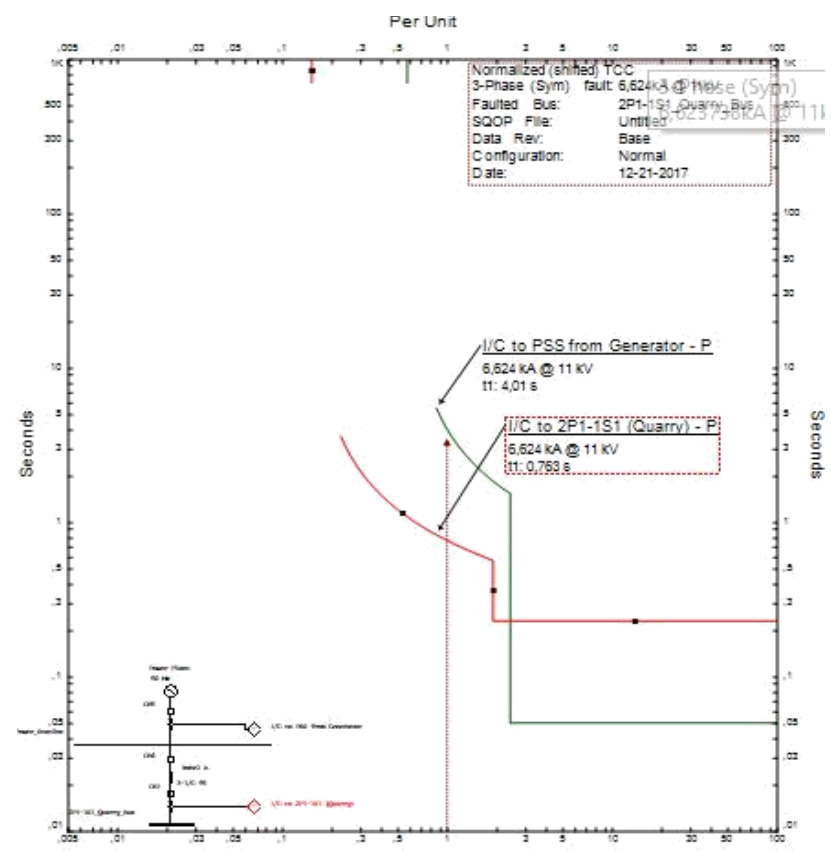

Fig. 7. Graph of TCC in the application at PT Indocement Tunggal Prakarsa Plant 12

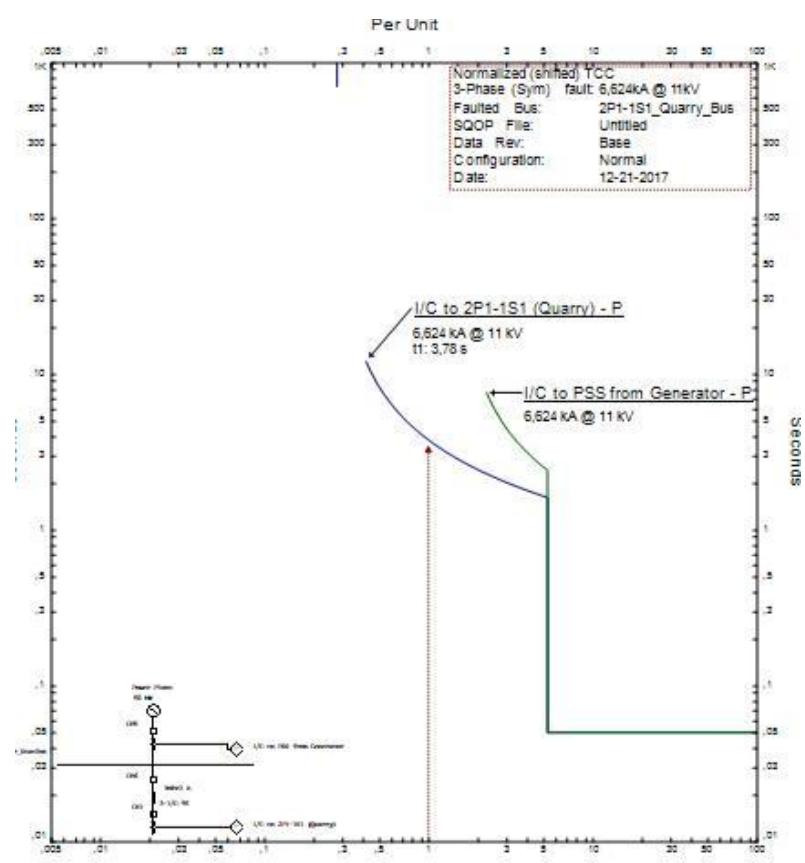

Fig. 8. Graph of TCC using conventional calculation

From the TCC graph, which has been simulated both from the field, the manual and ETAP software are running well. This is shown in the picture at field level, manual, and ETAP software relays work sequentially, which distinguishes only the margin time between relays on the field shows a marginal time of 3.25 seconds, at a marginal time level of 3.01 and using software ETAP 2.16 with a margin time standard is $0.2-0.3$ based on the IEEE 242 standard.

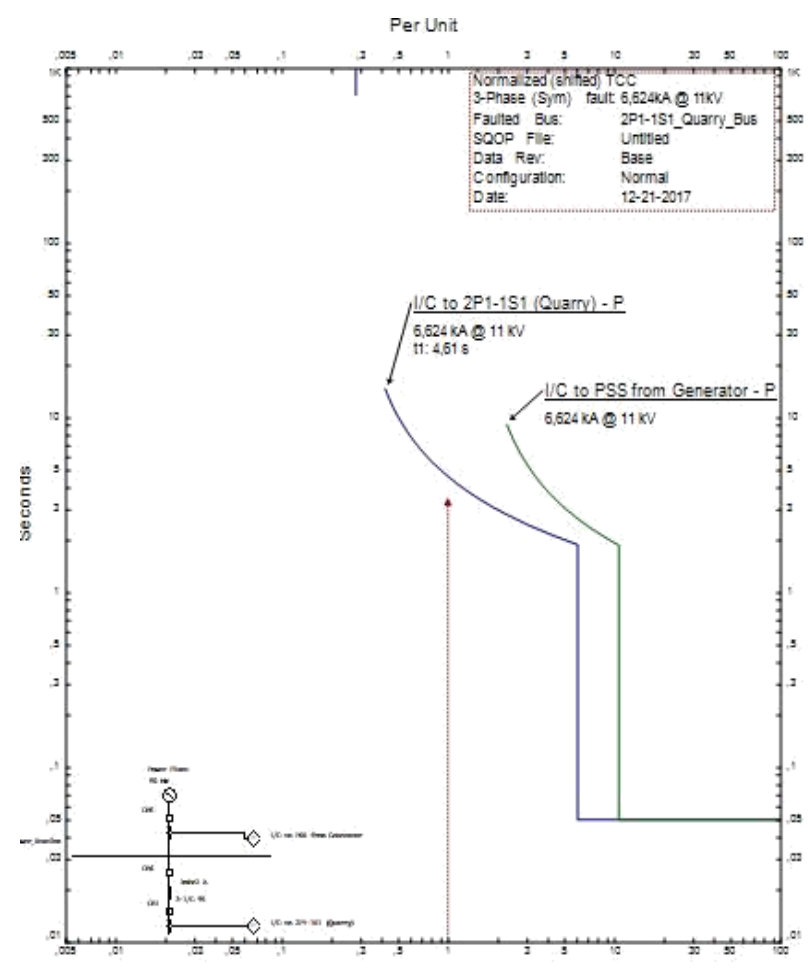

Fig. 9. Graph of TCC using ETAP simulation

\section{Conclusion}

Coordinaton of overcurrent relay protection already installed in the field still does not meet the standard for overcurrent relay protection coordination. After observing the performance of coordination settings for overcurrent relays in zones 3 to 7 in the primary and backup relay simulation tests, the fuse has a very long break time. It is far from the standard of electricity. Observations on the Time Current Curve (TCC) also show the coordination of overcurrent relay installed in the field is running well. However, in the protection zone 3 to 5 , the fuse has a very long break time, so it is not following the work of the main relay and the backup that should be work first. The results of the calculation of the short circuit current using calculations with simulation ETAP software has a percentage of $14.99 \%$ in the 3 phase short circuit $1 / 2$ cycle and $24.97 \%$ for the 2 phase 30 cycle. On observations using TCC, the data obtained is more accurate than observing the coordination of overcurrent relays by merely observing the relay work. 


\section{References}

[1] A. Chowdhury, D. Koval, "Power Distribution System Reliability: Practical Methods and Applications" in Wiley-IEEE, Hoboken, NJ, Mar. 2009.

[2] N.K. Choudhary, S.R. Mohanty, and R.K. Singh. (2014). "Protection coordination of over current relays in distribution system with DG and superconducting fault current limiter", 2014 Eighteenth National Power Systems Conference (NPSC), Guwahati, India.

[3] C.W. So, K.K. Lee, "Overcurrent Relay Coordination by Evolutionary Programming", Electric Power System Research, vol. 53, pp. 83-90, 2000.

[4] C37.110-2007-IEEE Guide for the Application of Current Transformers Used for Protective Relaying Purposes; Revision of Std C37.110-1996; NJ, USA:IEEE: Piscataway, pp. 1-90, 2008.

[5] R. Djayasinhe, D. Mutumuni, "Modeling the saturation of current transformers for the study of relay protection devices", Releyshik., vol. 2, pp. 4446, 2014

[6] A.A. Voloshin, E.A. Voloshin, S.S. Usachev, A.R. Ententeev, B.T. Maksudov, "Application of technology of internet of things in power engineering for implementation of operational monitoring of damages in low voltage electrical networks for estimate technical condition of equipment and controlling of reliability of power distribution energy system Collection of the VIII international conference "ehlektroehnergetika glazami molodyozhi", Samara., pp. 267, 2017.

[7] B. Hussain, S. Sharkh, S. Hussain, "Impact studies of distributed generation on power quality and protection setup of an existing distribution network", Proc. Int. SPEEDAM, pp. 1243-1246, 2010.

\section{Authors' information}

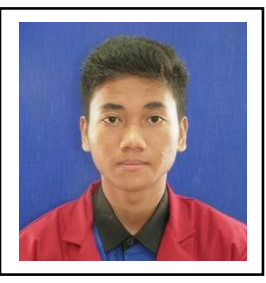

Aditiya Setiawan received B.Sc. degree from Department of Electrical Engineering, Universitas Muhammadiyah Muhammadiyah Yogyakarta, Yogyakarta, Indonesia in 2018. His research interests are in operation of power system protection and power system planning.

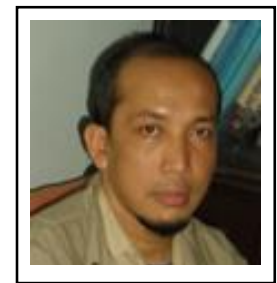

Ramadoni Syahputra received B.Sc. degree from Institut Teknologi Medan in 1998, M.Eng. degree from Department of Electrical Engineering, Universitas Gadjah Mada, Yogyakarta, Indonesia in 2002, and Ph.D degree at the Department of Electrical Engineering, Faculty of Industrial Technology, Institut Teknologi Sepuluh Nopember, Surabaya, Indonesia in 2015.
Dr. Ramadoni Syahputra is a Lecturer in Department of Electrical Engineering, Faculty of Engineering, Universitas Muhammadiyah Yogyakarta, Indonesia. His research interests are in computational of power system, artificial intelligence in power system, power system control, the application of fuzzy logic in power system, optimization, distributed energy resources, and renewable energy.

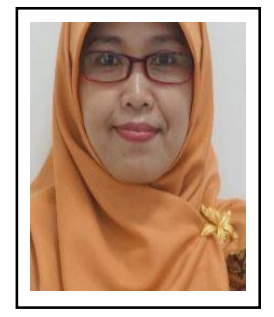

Anna Nur Nazilah Chamim obtained her B.Eng. in Electrical Engineering from Universitas Muhammadiyah Yogyakarta, Indonesia. Her Master study was done at 2015 at the Electrical Engineering, Universitas Gadjah Mada, Indonesia. She currently is a lecture in department of Electrical engineering, Universitas Muhammadiyah Yogyakarta. Her main research interest is in electronics, telecommunication, and signal processing.

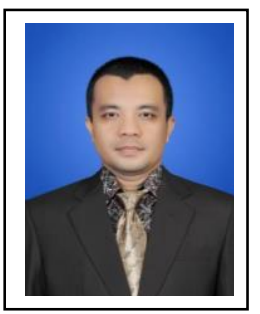

Jeckson obtained his B.Eng. in Electrical Engineering from Universitas Muhammadiyah Yogyakarta, Indonesia, in 1999. His Master study was done at 2015 at the Electrical Engineering, Universitas Negeri Padang, Indonesia. She currently is a lecture in department of Electrical engineering, Universitas Muhammadiyah Lampung. His main research interest is in powe sistem analysis, energy conversion, power electronics, and power system protection. 